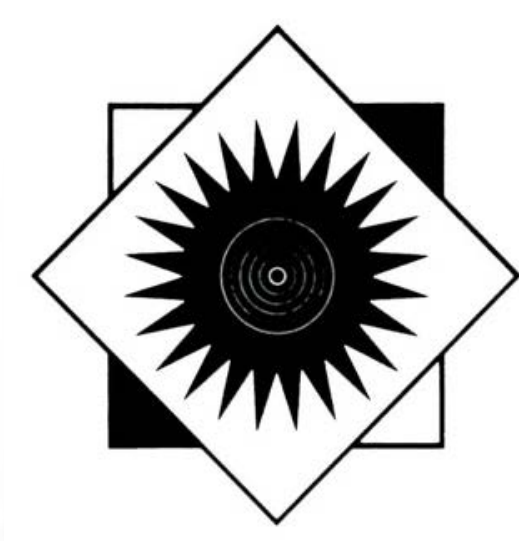

\title{
INNOVATIONS
}

\section{Creativity, innovation and risk-taking}

\author{
By Joanne R. Euster \\ ACRL Vice-President/President-Elect
}

As ACRL President-Elect, I have chosen a theme for the coming year that focuses on "Fostering Creativity and Innovation"-in ACRL, in our jobs, in our professional lives. This column begins what I hope will be a continuing series of short articles by ACRL members about creative and innovative activities in their libraries and in the profession.

One of the critical questions in thinking about creativity, to my mind, is how bureaucratic, highly structured organizations-our academic libraries - can encourage creative thinking and innovative behavior. We are tightly bound by policies, manuals of procedure, guidelines, standards, rules and by-laws in our association as well as in our jobs, leading one to wonder, would "the ACRL guidelines for creative thinking in libraries" be an oxymoron? Certainly publishers and authors would like us to think otherwise. Books like $A$ Whack on the Side of the Head, Conceptual Blockbusting, Drawing on the Right Side of the Brain, Writing the Natural Way, and Winning at the Innovation Game, as well as myriad more scholarly books and journals, promise that creativity can be taught and that innovation can be developed systematically.

"Creativity: The Human Resource" was an exhibit presented by the California Academy of Sciences in 1979. The exhibit included ideas, illustrations, mind games and puzzles. Throughout, it illustrated how creative people do seven things:

- They challenge assumptions by daring to question what most people take as truth.

- They recognize patterns, perceiving significant similarities or differences in ideas, events or physical phenomena.

- They see the commonplace in new ways.

- They make connections between seemingly unrelated ideas.

- They take risks by trying new ways or ideas with no control over the outcome.

- They use chance, by taking advantage of the unexpected.
- They construct networks, forming associations between people for an exchange of ideas, perceptions, questions, and encouragement.

"Most Effective College Presidents are 'Risk Takers" "was the Chronicle of Higher Education headline of November 5, 1986, reporting a Council for Advancement and Support of Education study. "Most effective presidents" were nominated by their colleagues, who were also asked to identify the leadership qualities which made them effective. Effective leaders were found to take more risks and to encourage others to be creative as well, among other qualities.

What is risk-taking, anyway? Words like "pilot project," "experiment," or "test" don't seem so threatening, yet they are really risks broken down into small, manageable pieces. Most of us find the risks involved in big multi-thousand or million dollar systems or projects frightening. Nevertheless, doing nothing is often the biggest risk of all, just as refusing to decide is also making a decision. Breaking down a risk into component parts, managing it sequentially with frequent evaluations and continue/discontinue checkpoints and calling each step by a less threatening name, such as "trial project" helps to take the threat out of risks and make them more acceptable.

Similarly, if risks are de-personalized they are easier to cope with. Making the risk-the experiment-an organizational activity rather than a personal one takes much of the ego involvement out of the risk. Every experiment, by its very nature, has in it the inherent chance of failure, partial failure or partial success as well as of success. New ideas and directions often come from failed experiments, however, when the project is managed in such a way that failure of the experiment is not equated with failure of the person. I think it is essential for us to foster an atmosphere in which risk-taking and experimentation are encouraged and rewarded, not feared and punished.

The purpose of this column is to provide a forum 
for sharing experiments and innovations and for encouraging others to join in by contributing ideas and perceptions. Short articles should be sent to George Eberhart, Editor, College \& Research Li- braries News, at the ACRL office. Other ideas or comments can be sent to me at Rutgers University Libraries, 169 College Avenue, New Brunswick, NJ 08903.

\title{
The Management Intern Program at the Columbia University Libraries
}

\author{
By Louise S. Sherby \\ Reference Librarian, Humanities and History Division \\ Columbia University
}

Recognizing the importance of providing development opportunities for professional staff in a large, complex, decentralized library system, the Columbia University Libraries established the Management Intern Program in 1985 with the objective of introducing experienced library staff members to the responsibilities of senior management positions. Modeled on the internship program operated by the Council on Library Resources, the Libraries' internship program provides the opportunity for librarians to spend a six-month period observing and participating in the various activities of a senior staff member, with the ultimate goal of expanding the interns' own skills and abilities and allowing them to become more informed about the responsibilities and skills needed to perform successfully as senior managers.

In addition to enhancing the career options of the interns, the program aims to develop the interns' awareness of the library system at different levels, provide a system-wide perspective rather than a departmental or divisional perspective, and involve them in the policy formulation process. Through performance of specific assignments as well as participation in committee meetings, the interns also contribute in a significant way to the Libraries during this time period.

The Internship Program is a competitive one. Prospective interns are required to write a letter of application stating why they are interested in the program, whom they wish to work with, and their objectives and goals for participation. The applications are submitted to a committee of three senior managers for review. The successful applicant is notified by Patricia Battin, vice president for information services and university librarian. To be eligible for the intern program, staff members must have five years of experience as librarians and have worked in a supervisory or managerial capacity for some part of this time. During the six-month internship period, the intern is released from regular duties and is assigned to a senior administrator at the level of assistant university librarian, director, assistant director, or librarian of a distinctive col- lection, with whom the intern works closely on particular areas of concentration.

The two interns who have participated in the Internship Program to date have both come from public services areas. The 1985/86 intern was Jane Winland, the business and economics librarian, and the 1986/87 intern was Louise Sherby, reference librarian, Humanities and History Division. Winland had twelve years experience as a frontline reference librarian and four years as a departmental librarian; Sherby had sixteen years experience as a reference librarian, including six years as head of a reference department in a college library.

Jane Winland worked with Paula T. Kaufman, director of the Academic Information Services Group, and Louise Sherby worked with Charling Chang Fagan, assistant director for social sciences, and then with Paula Kaufman for six weeks when Charling Fagan began a previously planned leave of absence. Kaufman directs the public services operations of the libraries, Humanities and History Division, Science and Engineering Division, and Social Sciences Division, and the Columbia University Center for Computing Activities, User Services Group. Fagan is responsible for directing the activities and operations of four departmental libraries in the social sciences-the Lehman Library (social sciences and international affairs), the Business and Economics Library, the Social Work Library, and the Journalism Library.

Participants in the program accept the many responsibilities inherent in such an activity. Perhaps the major responsibility for the senior staff member to whom an intern is assigned is a commitment to the goals of the program and the ability to spend a significant amount of time with his/her assigned intern. It is important for the two participants to agree on specific objectives and to develop a real working relationship. Talking about problems, plans, and other agenda items and soliciting each other's opinions are integral parts of the process. In addition, it is important for the intern to have an assigned workstation or office close at hand to the staff member so that the intern will be available to 